\title{
The Analysis of Senior High School Students' Mathematical Communication Skill of Trigonometric Material
}

\author{
Upi Lidinillah $^{1}$, Endang Cahya M.A. ${ }^{2}$ \\ \{upilidinillah@upi.edu ${ }^{1}$, endangcahya@gmail.com ${ }^{2}$ \} \\ Mathematics Education Study Program, School of Postgraduate, Universitas Pendidikan \\ Indonesia, Jl. Dr. Setiabudi No. 229, Bandung 40154, Indonesia ${ }^{1}$, Mathematics \\ Education Department, Universitas Pendidikan Indonesia, Jl. Dr. Setiabudi No. 229, \\ Bandung 40154, Indonesia ${ }^{2}$
}

\begin{abstract}
Math is required for students in order to have mathematical communication skills. This research was aimed to analyze the students' mathematical communication skill on trigonometric material. This research utilized a qualitative approach in the form of a case study. There were six students from science major as the subject of the research. The data collection technique utilized tests and interviews. The data analysis techniques were conducted by data reduction, presentation of data, and drawing conclusion/verification. The research finding presented that the students' mathematical communication skill is deficient. The causative factor because which some students can not hook real objects, pictures, and diagrams into mathematical ideas, inappropriate symbols used and explain the mathematical model perfectly. Students made types of mistakes such as adversity in communicating the mathematical model, misunderstanding about the questions and wrong variable concept used.
\end{abstract}

Key words : Mathematical Communication Skill, Trigonometry

\section{Introduction}

Communication skill is one of the main support for student success in learning the subjects at the school. Mathematical communication is a required skill to be given to students in math. Mathematical communication skill is a means on how students assert and interpret the ideas orally as well as in writing, either in the form of pictures, tables, diagrams, formulas or demonstrations [1]. Communicating orally and in writing in math class can help deepen their conceptual understanding. When students are encouraged to interact with others, they are able to build individual understanding and ordering of concepts [2]. The mathematical communication process can also give students the opportunity to share ideas [3].

The urgency to have mathematical communication skill is (1) power for students in formulating the mathematical concept; (2) the basis success for students toward completion of mathematical exploration and investigation; (3) a place for students to communicate with classmates in order acquiring information, sharing notion and discovery, giving an opinion, evaluating and sharpening the ideas to ensure others [4]. Low mathematical communication skill can encumber the students in the learning process nevertheless if students' mathematical students' skill is good, it will bring a good impact both on students and teachers. From 
mathematical communication skills, teachers can observe the students who have mastered the material and those who have not mastered the material [5].

Nevertheless, based on the result of the research, it was shown that the written students' mathematical communication skills were in low categories, such as (1) unable to present the problems into mathematical model precisely; (2) unable to conduct the steps of the solving problems appropriately (3) incapable to obtain a final solution from students work results; (4) unable to interpret the mathematical solution acquired [6]. Especially in determining mathematical models such as in trigonometric material.

Trigonometry is a part of mathematics that is pertinent with angles of triangle and trigonometric function [7]. Trigonometry is necessary to be learnt for senior high school students because students must be able to relate triangular diagrams to numerical relationships and manipulate the symbols involved in these relationships [8]. In 2019, Trigonometry always appears on the National Examination (UN). Trigonometry must be mastered for class X SMA on math textbook of curriculum 2013, such as (1) trigonometric formula of right triangle; (2) angle of elevation and depression; (3) special angle on trigonometry; (4) sine and cosine rule; (5) trigonometric functions [9].

Trigonometry is an area of mathematics that students believe to be particularly difficult and abstract compared with the other subjects of mathematics [10]. Based on the data collected, explaining that the problem with algebraic, calculus, statistic, geometry and trigonometry always appears on the National Examination (UN). But in reality, comprehension of trigonometric material to students of senior high school of science program year 2018/2019 is low category, compared to other materials examined in the district, province, and national level. The following is the data percentage of material mastery in the questions of Senior High Shcool National Examination of Science Program academic year 2018/2019 [11].

Table 1. The percentage of students' correct answers of Mathematic National Examination Academic Year 2018/2019

\begin{tabular}{clc}
\hline No. & \multicolumn{1}{c}{ Material Tested } & National \\
\hline 1. & Algebraic & 45,49 \\
2. & Calculus & 34,99 \\
3. & Geometry and Trigonometry & 34,59 \\
4. & Statistic & 35,02 \\
\hline
\end{tabular}

From the table 1, the students' percentage who answered geometry and trigonometry correctly are $34,59 \%$ from the total students 973.252 participating in the National Examination, geometry and trigonometry materials are in low level among other materials tested.

Table 2. Students' Percentage who Answered Correctly the Trigonometry of Mathematics National Examination for Academic Year 2018/2019

\begin{tabular}{clcc}
\hline $\begin{array}{c}\text { Serial } \\
\text { Number }\end{array}$ & \multicolumn{1}{c}{ The indicator Tested } & National \\
\hline 22 & $\begin{array}{l}\text { Determine the value of a trigonometric ratio in various } \\
\text { quadrants }\end{array}$ & 21,89 \\
23 & $\begin{array}{l}\text { Determine the graphic picture from a trigonometric function } \\
24\end{array}$ & $\begin{array}{l}\text { Accomplish the contextual problem related to sine rule and/or } \\
\text { consine rule }\end{array}$ & 41,37 \\
38 & Accomplish the problem associated with consine rule & 28,09 \\
\hline
\end{tabular}


Based on the table 2, it can be perceived that the percentage results of all indicators are below 55,00 which mean the student has low absorption of trigonometric material, and quite complicated for students.

Student activities in learning trigonometry do not constantly perform well, remaining several students who carry on the obstacle in answering the trigonometric questions. There are some factors that become the obstacles for students' learning, (1) the obstacle of students' mental unreadiness to learn (ontogeny); (2) the obstacle to inaccuracy teaching and materials (didactic); (3) the obstacle to insufficient prerequisite knowledge (epistemological) [12]. Lack of development of the necessary prerequisite schemes makes the conceptualization of students' mathematical concepts fixed or not developed [13].

The barriers to students' learning in trigonometric materials have observed from research conducted by education practitioners. One of the research result presented that the mistakes done by all groups of students were an error in the form of deciding to utilize the strategy with elaborating each trigonometric comparison relationship which resulted in complicated calculations, the cause is the student's inability to determine the relationship between trigonometric formulas and identities; errors in writing the math operation symbols and errors in conducting count operation of algebraic form with the result that students are less comprehensive when doing the calculation [14]. In line with other studies which say that the mistakes students often make in solving trigonometric problems include; (1) misunderstanding that occurs when students do not understand how to solve trigonometric problems given from the concept; (2) transformation errors that occur during the computation process, especially during multiplication; (3) in the process of skills that are more visible in the use of the right triangle method formula [15].

This article is concerned about the analysis of senior high school students' mathematical communication skill on trigonometric material. students who have good mathematical communication skill will have the ability [16] : (1) connect the real things, pictures, and diagram into mathematical ideas; (2) explain the ideas, situations and mathematical relations orally or in writing with real objects, graphic images, algebra, (3) convey the daily events in the form of language or mathematical symbols. This research is intended to explore senior high school students' mathematical communication skills toward trigonometric problems, the factor that causes the students to perform mistakes and the types of students' mistakes in completing the mathematics question of trigonometric material.

\section{Method}

This research utilized the descriptive method in the form of a case study that explains about the development of something, revealing the cause and effect, and this research leads to present an overview of the existing situation. Whilst, the qualitative approach is used to describe the data collection in the form of words and sentences. This research was conducted in September. The subject of the research is 6 students at SMAN 3 Karawang. In this research, the researcher conducted a qualitative study in small scale that involved 6 students of senior high school students at science major. The data collection techniques were test and interview. The test is given to students only one time that is a written communication test in the form of essay questions consisting of three items. The interview was conducted to strengthen the result 
obtained from the written math communication skills test. After the data collection has completed, the next step is data analysis.

The data analysis techniques were conducted by data reduction, presentation of data, and drawing conclusion/verification [17]. Data reduction is an activity referring to the process organizing, selecting, simplifying and abstracting data obtained from the test results; presentation of data in this research is descriptive to provide the overview of presentable and organized information, therefore, there is a drawing conclusion from the data; drawing conclusion and verification are the activity to summerize and check the correctness of the data. To obtain the conclusion on this step, the factor that causes the students to perform mistakes in accomplishing the mathematics questions of trigonometric material and the types of students' mistakes in completing the mathematics question of trigonometric material.

\section{Result and Discussion}

In this research, six students of senior high school at science major were asked to accomplish the trigonometric problems. The results:

Table 3. The result of mathematical communication skill

Indicator of

Mathematical

Problems

S01 S02 S03 S04 S05 S06

Communication

1. To link the A rumble strip built transversely in real objects, the road with angle $30^{\circ}$ is like

pictures, presented on the following picture. and diagram into mathematic al ideas.

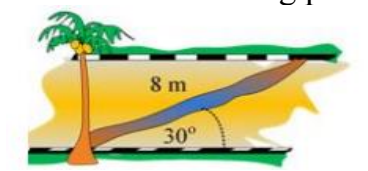

If the rumble strip's length is 8 meters, determine the wide of the road and explain it.

2. To state the daily events into Two cars depart with steady rate language and A the same time at 07.00 o'clock. The first car moves with $30 \mathrm{Km} / \mathrm{h}$ to the east heading to mathematic house B and arrives at 12.00 while al symbols. the second car goes with $16 \mathrm{~km} / \mathrm{h}$ heading to house $\mathrm{C}$ So it is like angle $60 \mathrm{o}$ from the east and arrive at 11.00 o'clock.

a. Make the mathematical model from the problems above 
b. Determine the distance from house B to house $\mathrm{C}$. Then write your reasons why do you apply sine and cosine rule to solve the problem.

3. To explain Draw a graphic function of $y=\sin$

the idea, $(3 \mathrm{x})$ where $0 o \leq x \leq \pi$, then

situations, determine the maximum turning

and point, minimum turning point and

mathematic explain it.

al relation

orally or in

writing with

the real

objects,

graphic

pictures,

and algebra.

Based on table 1, the test results of communication skills given to senior high school students of science major obtained that student $\mathrm{S} 01$ has a low ability because of the incapability to fulfill indicator 1. Student S02, S03, S04, S04, and S06 have already fulfilled the indicator 1. For indicator 2, student S01 and S04 have a low ability to meet indicator 2 while students S01, S02, S05 and S06 have already met the indicator 2. For indicator 3, students S01, S04, S05 and S06 have not fulfilled the indicator 3. The cause of students having low mathematical communication skills due to lack of mastery of the language of mathematics, misinterpreting or applying formulas, not being careful, rushing in solving problems, and forgetting concepts [18]. Here are some students' answers who have not attained their indicator of student's mathematical communication skills.

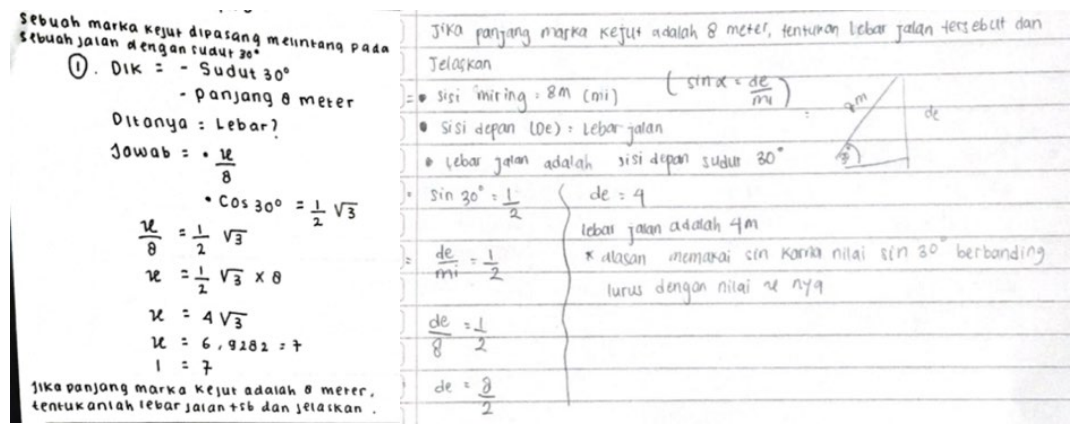


Fig. 1. Students answered problem 1

Figure 1 showed the students' answers of S01 and S06, it can be seen that student S01 is not able to link the real objects, pictures, and diagram into mathematical ideas on indicator 1 . Student S01 solved a problem formerly by using cosine which student should overcome by drawing a right triangle first to perceive the trigonometric comparison used. The researcher concluded from the student's writing that student does not still understand the material needed in the problems required in the questions, this caused the student was not able to fulfill indicator 1 which is contradictory with student's answer S06, that a student can connect the real objects into math indicator. Besides the correct answer, the student also provided clear reasons for solving the problem. Mathematical communication skills become important when discussions between students are carried out, where students are expected to be able to state, explain, describe, listen, ask and cooperate so that they can lead students to a deep understanding of mathematics [19]. Meanwhile, in this case, S01 students have not been able to state and describe the problem. The researcher interviewed with S01, the answer is the student did not remember the formula used.

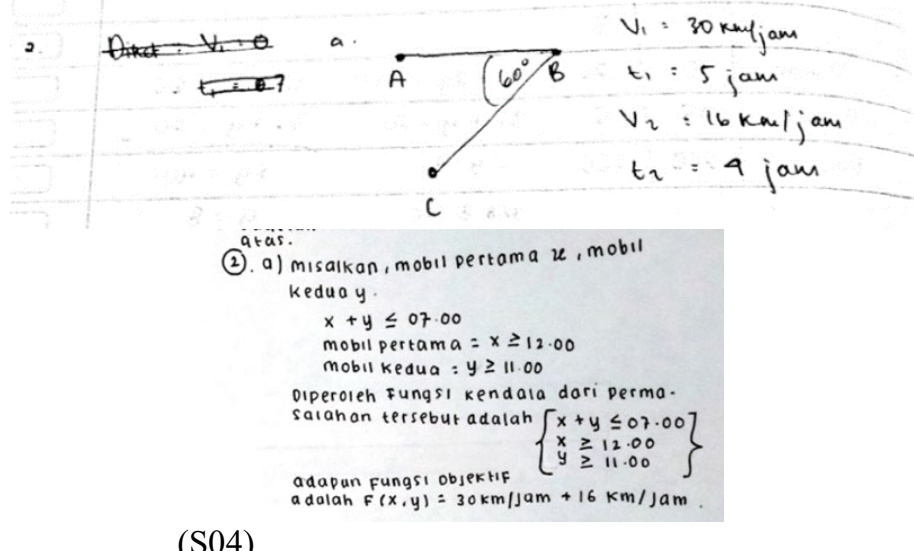

Figure $2 \mathrm{a}$ and $2 \mathrm{~b}$ presented that S01 and S04 are not able to state the daily events into language and mathematical symbols in indicator 2. Student S04 has completed the solving problem on part 2 a correctly however student has not figured out the speed of each car and student S01 used linear programming in solving the problem whereas it should not be applied. Students can answer immediately, by obtaining how the speed of each car heads to the city and afterwards, the model is drawn. The researcher interviewed with S04, the answer is the student imagined the concept to be used however student got confused to reveal it into a mathematical model. The interview result from student S01 merely understood the linear programming formula to solve the problem because a student did not know to answer using a trigonometric concept. 


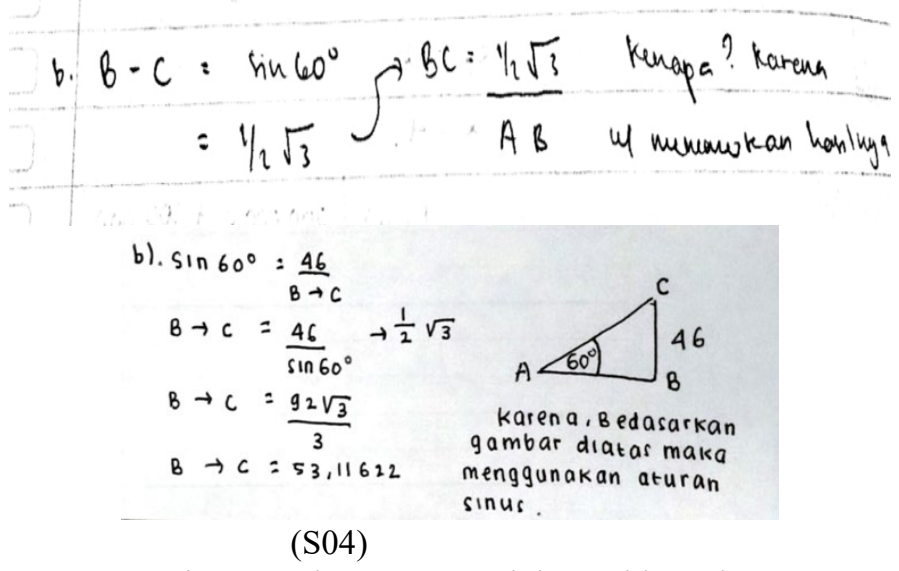

Fig. 3. students answered the problem $2 b$

Figure 2b student S01 and S04 have accomplished the problem using sine rule without providing a correct reason why they apply its rule. Students have less attention to trigonometric concept used that caused errors in answers. This is in accordance with research which reveals that during teaching trigonometric material, the difficulties that are carried out by students mostly lie in the basic concepts of the material. Students know the concepts given by the teacher but have difficulty applying these concepts to problem solving [20].

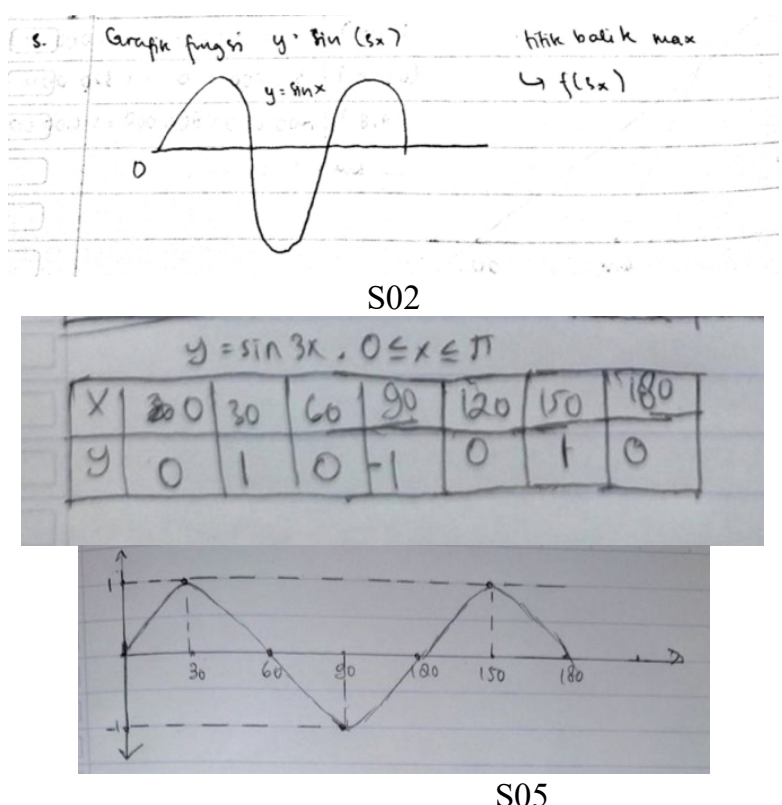

Fig. 4. students answered problem 3

Figure 3 indicated student S02 and S05. Based on their answers, students made a sketch and model that describe the problem from the question. Nevertheless, students merely have not been able to understand, explain and accomplish the problem very well. Student S02 
answered incorrectly, a student just remembered and visualized the graph of $\mathrm{y}=\sin \mathrm{x}$ when the form equation is changed then the student is not able to communicate and draw the graphic. If students are given a question that is different from the example problem they are confused because they don't know where to start from [21]. Different from student S05, a student could describe the graphic correctly however student was not able to reach indicator 3 . This is in line with the results of the analysis obtained when students worked on story questions with trigonometric material, the error rate was mostly done by students at the encoding error stage where students did not write conclusions [22]. The interview result from student S02, a student was only able to describe the graphic function of $y=\sin x$, a student will get confused to visualize the graphic if the question is changed, and the interview result from student S05 is adequate from answering the graphic function without being explained.

From the explanation of the research results above, in general the mistakes students do it because students do not understand what is being asked in the questions and have not been able to determine the formula or steps that should be used to solve the questions.

\section{Conclusion}

The research results presented that students' mathematical communication skill are deficient. The factors that cause students to perform mistakes that inflict to their mathematical communication skill in low category which some students can not hook real objects, pictures, and diagrams into mathematical ideas, inappropriate symbols used and explain the mathematical model perfectly.

Students made types of mistakes such as adversity in communicating the mathematical model, misunderstanding about the questions and wrong variable concept used. Based on this research, the researcher suggests that students must receive problems to be resolved by communicating into a correct mathematical model in order their mathematical communication skill are enhanced optimally.

Acknowledgments. The writer says thanks to Dr H. Endang Cahya Mulyaning A., M.Si. for the comments and suggestions given and also Headmaster of SMA at science major for the participation.

\section{References}

[1] Utami RA. Pengaruh Model Role Playing terhadap Kemampuan Komunikasi Matematis Siswa pada Materi Limit. Variabel. 2020;3(1):20-5.

[2] Lomibao LS, Luna CA, Namoco RA. The Influence of Mathematical Communication on Students' Mathematics Performance and Anxiety. Am J Educ Res [Internet]. 2016;4(5):378-82.

[3] Chung Y, Yoo J, Kim SW, Lee H, Zeidler DL. Enhancing Students' Communication Skills in the Science Classroom Through Socioscientific Issues. Int J Sci Math Educ. 2016;14(1):1-27.

[4] Ramadhani R, Harahap JY. Pengaruh Self Efficacy terhadap Kemampuan Komunikasi Matematis melalui Pembelajaran dengan Menggunakan Aplikasi SPSS. Logaritma J Ilmu-ilmu Pendidik dan Sains. 2020;8(01):27-40. 
[5] Rofikoh F, Winarti ER, Sumarni. Kemampuan Komunikasi Matematis Siswa pada Pembelajaran TTW Berbantuan Fun Card Ditinjau dari Kepercayaan Diri Siswa. Prism Pros Semin Nas Mat. 2019;2:432-8.

[6] Achir YS, Usodo B, Retiawan R. Analisis Kemampuan Komunikasi Matematis Siswa Dalam Pemecahan Masalah Matematika Pada Materi Sistem Persamaan Linear Dua Variabel (Spldv) Ditinjau Dari Gaya Kognitif. Paedagogia. 2017;20(1):78-87.

[7] Kariadinata R. Trigonometri Dasar. Bandung: Pustaka Setia; 2013.

[8] Weber K, Knott L, Evitts TA. Teaching Trigonometric Functions: Lessons Learned from Research. Natl Counc Teach Math. 2015;102(2):144-50.

[9] Sukino. Matematika untuk SMA/MA Kelas X 1B. Jakarta: Erlangga; 2014

[10] Gür H. Trigonometry learning. New Horizons Educ. 2009;57(1):67-80.

[11] Puspedik. Laporan Hasil Ujian Nasional, Pusat Penilaian Pendidikan Kementrian Pendidikan dan Kebudayaan Tahun 2018/2019. Puspedik.Kemendikbud.go.id; 2019

[12] Brousseau G. Theory of Didactical Situation in Mathematics. Dordrecht: Kluwer Akademic Publishers; 2002.

[13] Ngcobo AZ, Africa S, Madonsela SP, Africa S, Brijlall D, Africa S. The teaching and learning of trigonometry. Indep J Teach Learn. 2019;14(2):72-91.

[14] Jingga AA, Mardiyana, Setiawan R. Analisis kesalahan siswa dalam menyelesaikan soal identitas trigonometri pada siswa kelas x semester 2 sma negeri 1 kartasutra tahun ajaran 2015/2016. J Pendidik Mat dan Mat. 2017;1(5):48-62.

[15] Usman MH, Hussaini MM. Analysis of Students' Error in Learning of Trigonometry Among Senior Secondary School Students in Zaria Metropolis, Nigeria. IOSR J Math. 2017;13(02):014.

[16] Jihad. Pengembangan Kurikulum Matematika. Bandung: Multi Pressin; 2008.

[17] Miles MB, Huberman AM. Analisis Data Kualitatif: Buku Sumber Tentang Metode-Metode Baru, Terjemahan oleh Tjetjep Rohendi Rohidi. Jakarta: UI-Press; 1992.

[18] Otay MI, Mohidin AD, Ismail S. Analisis Kesalahan Siswa dalam Menyelesaikan Soal-soal pada Materi Garis Singgung Lingkaran. Jurnal Pendidikan Matematika. 2013;1(1):1-11.

[19] Within. Mathematics Task Centre; Proffesional Development and Problem Solving. In J Wakefield and L. Velardi (Ed). Celebrating Mathematics Learning. Melbourne: The Mathematical Association of Victoria; 1992.

[20] Hidayat, W., \& Aripin, U. (2020). Identifikasi Kesalahan Jawaban Mahasiswa Pada Mata Kuliah Trigonometri Berdasarkan Dimensi Pengetahuan Krathwohl. JNPM (Jurnal Nasional Pendidikan Matematika), 4(1), 142.

[21] Ansari BI. Komunikasi Matematik. Banda Aceh: Yayasan Pena; 2009.

[22] Savitri DA, Anik Y. Analisis Kesalahan Siswa dalam Menyelesaikan Permasalahan Ttigonometri Ditinjau Dari Gender Berdasarkan Newman. Jurnal Pembelajaran Matematika Inovatif. 2020; 3(5):463 - 474 . 